\title{
Augustin Kažotić i Toma Akvinski
}

\author{
ANTO GAVRIĆ \\ Fakultet filozofije i religijskih znanosti \\ Sveučilišta u Zagrebu \\ anto.gavric@ffrz.unizg.hr \\ UDK 1Thomas Aquinas, sanctus \\ 27-36Kažotić, A. \\ $141.30 " 12 / 13^{\prime \prime}$ \\ Izvorni znanstveni rad \\ Primljen: 29. 5. 2021. \\ Prihvaćen: 15. 6. 2021. \\ https://doi.org/10.52685/pihfb.47.1(93).1
}

\begin{abstract}
Sažetak
Proučavanje prve generacije učenika Tome Akvinskoga ostalo je još uvijek dosta neistraženo. Studije o prvim Tominim učenicima osobito su značajne za poznavanje načina kako se prenosila i u kojim sve područjima misao Zajedničkog naučitelja (Doctor communis). Stoga i ovaj prilog ulazi u to područje istraživanja. Članak najprije prikazuje kako se stoljećima u raznim izvorima isticalo da je Augustin Kažotić bio izravni učenik Tome Akvinskoga te da je pohađao njegova predavanja za vrijeme studija na sveučilištu u Parizu. Zatim doktrinarno analizira kontekst Augustinova boravka na studiju u Parizu pokazujući da je Tomin nauk još uvijek bio živo prisutan u akademskim krugovima. Autor nadalje potvrđuje kako je dominikanski red imao važnu ulogu u porastu doktrinarnog utjecaja Tome Akvinskog te pokazuje da je u tome i Augustin Kažotić dao svoj doprinos. Stoga autor argumentirano analizira Kažotićevu povezanost s Tomom Akvinskim na nekoliko doktrinarnih područja. Na kraju prosuđuje i doprinos Augustina Kažotića kanonizaciji Tome Akvinskog. Članak potvrđuje kako je život i djelo Augustina Kažotića značajno svjedočanstvo za poznavanje prenošenja misli sv. Tome Akvinskoga, posebice u razdoblju prije same njegove kanonizacije.
\end{abstract}

Ključne riječi: Augustin Kažotić, Toma Akvinski, transupstancijacija, siromaštvo, tomizam

\section{Uvod}

Otkrivajući povijest tomizma 20. stoljeće obilježeno je, između ostalog, značajnim naporom da se djelo i nauk Tome Akvinskoga smjesti u njegov kon- 
tekst. ${ }^{1}$ Unatoč tom znatnom naporu, povijest tomizma i utjecaja Tome Akvinskoga još nije dovoljno poznata. Postoje važne, vrijedne i cjelovite studije o pojedinim razdobljima te povijesti, ali ima drugih razdoblja koja su još uvijek nepoznata ili slabo istraživana. Naime, razdoblje od vremena profesorske službe dominikanca Tome Akvinskoga i profesorske aktivnosti franjevca Ivana Duns Škota, ostalo je dugo vremena u zaboravu u istraživačkom radu povjesničara teologije i filozofije, koje su više privlačila dva velika učitelja, a koji su zbog svojih slavnih imena i slaboga poznavanja njihove misli, postali nehotice predvodnici dviju škola: tomističke i skotističke (dominikanske i franjevačke). Srećom, oni koji danas proučavaju povijest doktrina sve su svjesniji važnosti naraštaja teologa i filozofa koji popunjava tu naizgled prazninu, kako bi bolje shvatili njihove predšasnike a posebice njihove nasljednike.

Jedan od znakova zasigurno je i porast zanimanja za razdoblje između smrti Tome Akvinskoga i sredine 14. stoljeća nedvojbeno su brojna izdanja tekstova iz toga razdoblja. Danas znatno lakše dolazimo do filozofskih i teoloških spisa, čak i do kritičkih izdanja autora poput Henrika iz Genta, Egidija Rimskoga, Gottfrieda iz Fontainesa, Jakova iz Viterba, Dietricha iz Freiberga, Thomasa Suttona, franjevaca Rikarda iz Middletona (Richardus de Mediavilla), Mateja iz Aquasparte, Petra Olivija i dr.

Znak zanimanja za povijest tomizma pokazuje se, između ostalog, i po studijama koje se odnose na prve učenike Tome Akvinskoga, koji su od velikoga značenja za poznavanje prenošenja misli Zajedničkog naučitelja (Doctor communis), jer kao što piše francuski dominikanac Serges-Thomas Bonino, $»<\ldots>$ odvojiti sv. Tomu - pa i kontekstualiziranog u najvećoj mjeri - od tradicije koja ga je prenosila do nas značilo bi u konačnici upasti u zamku koju se htjelo izbjeći: učiniti od sv. Tome nadpovijesnog mislioca (koji nadilazi povijest), a od tomizma platoničku Ideju «. ${ }^{2}$

Proučavanje prvoga naraštaja Tominih učenika ostalo je još uvijek prilično neistraženo. Stoga je i ovaj prilog doprinos tom području istraživanja; i na hrvatskom jeziku objavljena su kritička izdanja dviju rasprava Augustina Kažotića. ${ }^{3}$

${ }^{1}$ Za uvodni dio usp. Anto Gavrić, Une métaphysique à l'école de Thomas d'Aquin. Le 'De modis rerum'de Rémi de Florence († 1319) (Fribourg: Academic Press, 2006), pp. 9-10.

${ }^{2}$ Serge-Thomas Bonino, »Avant-propos: Le thomisme et son histoire«, Revue Thomiste 97 (1997), p. 6.

${ }^{3}$ Augustin Kažotić, Bogoslovni spisi - Scripta theologica, priredio Franjo Šanjek (Zagreb: Kršćanska sadašnjost, 2007). 


\section{Augustin kao Tomin učenik u spisima povjesničara}

Nerijetko se u djelima povjesničara Reda propovjednika uz pojedine istaknute dominikance iz druge polovice 13. stoljeća isticala povezanost s Tomom Akvinskim. Iako nije bilo čvršćih dokaza i sigurnih svjedoka, ta se značajka rado navodila. Tako se, na primjer, spominje da je talijanski dominikanac Nikola Boccassino, kasnije vrhovni poglavar Reda propovjednika, kardinal te papa Benedikt XI, slušao Tomina predavanja u Parizu. A u stvari, Nikola Boccassino imao je priliku upoznati Tomu kada je 1263. prolazio kroz Milano. »Hagiografi su u svojoj fantaziji taj susret pretvorili u pohađanje Akvinčevih pariških predavanja, a to se u stvarnosti nije nikada dogodilo. « No nemajući ipak dokaze za takvu tvrdnju, drugi autori ističu da nije ni nužno da je Nikola Boccassino bio Tomin učenik u Parizu. »Znamo da je studirao u Italiji za vrijeme dok je sveti naučitelj držao javna predavanja iz teologije u Bologni, Rimu ili Napulju. Pod takvim učiteljem mogao je samo dobro napredovati«, ističe sredinom 18. stoljeća francuski povjesničar Antoine Touron. ${ }^{5}$ Štoviše, talijanski dominikanac Domenico Maria Marchese piše da su papa Benedikt XI. i Augustin Kažotić bili školske kolege u Parizu (Augustin je dvadeset godina mlađi od pape Benedikta XI.). ${ }^{6}$

O Kažotićevu životu i radu pisali su brojni povjesničari. Stoljećima se često u raznim izvorima spominjalo da je Augustin Kažotić bio učenik svetoga Tome Akvinskoga te da je slušao njegova predavanja za vrijeme svoga studija na sveučilištu u Parizu. Radi ilustracije donosimo ovdje nekoliko primjera.

Tako francuski dominikanac, poznati bibliograf i povjesničar Jacques Quétif u svom glavnom djelu Scriptores Ordinis Praedicatorum, koje je dominikanac Jacques Échard dovršio nakon njegove smrti i objavio 1719-1721. piše za blaženog Augustina Kažotića (B. Augustinus Gazothus):

»Neki izmišljaju da je bio učenik svetog Tome, zbog toga što se potpuno izvrće godina koje je pristupio Redu. Pio donosi da je poslan u Pariz radi studija

${ }^{4}$ Vito Sibilio, Benedetto XI: il papa tra Roma e Avignone (Roma: Istituto Storico Domenicano, 2004), p. 43.

${ }^{5}$ Usp. Antoine Touron, Histoire des hommes illustres de l'ordre de saint Dominique, t. I, knj. VII (Paris: Babuty, 1743), pp. 657-658.

${ }^{6}$ Usp. Domenico Maria Marchese, Sagro Diario Domenicano (Napoli: Nella stamparia di Giacinto Passaro, 1676), t. IV, p. 292b: »Conoscea molto bene Agostino il Pontefice, essendo stato suo Condiscepolo in Pariggi, e sapea non poter fare meglior elettione d'esso in quei tempi così torbidi per l'Vngheria.«»Papa je vrlo dobro poznavao Augustina, s kojim je bio suučenik u Parizu, i znao je da ne može napraviti bolji izbor od njega u tim teškim vremenima za Ugarsku.« 
1286., i to je najvjerojatnije. To je naime bilo uobičajeno, osobito u udaljenim provincijama za one za koje je proizlazila veća sigurnost o tome kakav je bio. « ${ }^{7}$

Jacques Quétif navodi da su neki izmislili da je Augustin Kažotić slušao predavanja svetoga Tome, ne navodeći poimence te izvore. Nadalje ističe da je poslan u Pariz radi studija 1286. godine te se poziva na ono što piše bolonjski dominikanac Giovanni Michele Piò, autor djela Delle vite degli huomini illustri di S. Domenico (Bologna, 1607). ${ }^{8}$ No Michele Piò ne spominje da je Kažotić bio Tomin učenik.

Trideset godina kasnije, 1637. dominikanac Sigismund Ferrarius objavljuje djelo De rebus Ungaricae Provinciae Ordinis Praedicatorum u kojem na sedam poglavlja i 27 stranica daje važan doprinos za hagiografiju Augustina Kažotića. ${ }^{9}$ I Ferrarius svjedoči da se prenosi predaja, iako neutemeljena, o tome kako je Kažotić bio Tomin učenik.

»Ako je taj vremenski odnos, koji je Plodije potvrdio mnogim utjecajnim piscima, istinit, ne vidim kako je blaženi Augustin mogao biti učenikom sv. Tome Akvinskog, Anđeoskog naučitelja, kao što su više puta tvrdili iznimni muževi prema istini stvari, s obzirom na to da je Sveti naučitelj preminuo već godine Gospodnje 1274., dakle dvanaest godina prije jer je bila 1286. godina kada je Augustin zbog studija krenuo u Pariz.« ${ }^{10}$

Ferrarius svoj prikaz Kažotićeva života započinje ističući kako je nedavno dobio na čitanje Augustinov životopis što ga je, na temelju raznih svjedočanstava, sastavio Ivan Tomko Mrnavić (1580-1637), ${ }^{11}$ bosanski biskup, a on

${ }^{7}$ Jacobus Quetif - Jacobus Echart, Scriptores Ordinis Praedicatorum, t. I (Paris, 1719), p. 553: »S. Thomae auditorem fuisse quidam comminiscuntur, quod ex anno quo nomen dedit ordini omnino evertitur. Parisios missum studiorum causa anno MCCLXXXVI narrat Pius, et verisimillimum: id enim vulgare, praesertim de moratioribus provinciarum externarum, et de quibus major spes affulgebat, qualis erat.«

${ }^{8}$ Michele Piò, Delle vite degli huomini illustri di S. Domenico, Parte Prima, lib. I (Bologna: Appresso Gio. Battista Bellagamba, 1607), pp. 241-242; (Bologna, 1620), lib. II, pp. 322-323 (Agostino d'Ongheria, Agostino Casatti).

${ }^{9}$ Sigismundus Ferrarius, De rebus Vngarica Provincice Sacri Ordinis Prodicatorum (Viennæ Austriæ: Typis Matthei Formicæ, 1637), pp. 115-142.

${ }^{10}$ Sigismundus Ferrarius, De rebus Vngarica Provincice, p. 116: »Quae ratio temporis a Plodio ex multis grauibus auctoribus assignata, si vera est, non video, quomodo B. Augustinus potuerit esse S. Thomae Aquinatis Ange. D. auditor, ut non semel asserunt Viri eximii, sive juxta rei veritatem, cum S. Doctor mortalitatem jam exuisset anno Christi 1274. nimirum ante annos duodecim, quoniam esset annus 1286. quando studiorum causa Augustinus Parisios proficiscebatur.«

${ }^{11}$ Ioannes Tomco, »Vita Beati Augustini Ordinis Prædicatorum, ex Zagrabiensi Lucerini Episcopi, per Ioannem Tomcum, Marnavitium, Bosnensem Episcopum, Lectorem \& Coadiutorem Zagrabiensem, fideliter collecta«, u: Sigismundus Ferrarius, De rebus Vngarica Provincice, Appendix, pp. 1-44. 
ga je kao dodatak uvrstio u svoje djelo De rebus Ungaricae Provinciae. Ipak Ferrarius navodi datiranje Kažotićeva dolaska na studij u Italiju, a zatim u Pariz na temelju onoga što je zabilježio već spomenuti Giovanni Michele Plodio slijedeći brojne ozbiljne autore (ex multis grauibus auctoribus). Stoga se i sam čudi jer, ako je točno vrijeme koje navodi Plodio (Michele Piò), ne vidi kako je Augustin mogao slušati predavanja Anđeoskog naučitelja (Angelici doctoris), kad je Toma preminuo 1274. godine, dvanaest godina prije nego je Augustin došao u Pariz. Augustin je tek 1286. godine krenuo na studij u Pariz, prema odredbi Opće skupštine Reda propovjednika održane 1286. u Parizu. ${ }^{12}$ Ferrarius na istome mjestu spominje da je po nekoj drugoj kronologiji Augustin umro kao »sedamdesetogodišnjak, i to 1332. što je 57 godina nakon smrti svetog naučitelja « te da je Anđeoskom naučitelju posvetio i jedno svoje djelo, »što uopće nije vjerojatno jer u to vrijeme možda još nije ni stupio u red « (quod haudquaquam credibile est, cum fortasse ea aetate nec ordinem fuerit ingressus). ${ }^{13}$

No Ivan Tomko Mrnavić u svome životopisu blaženog Augustina Kažotića ističe da je Kažotić kao biskup u Luceri, uz pobožnost prema Blaženoj Djevici Mariji, posebice častio svetog Petra Veronskog, prvoga dominikanskog mučenika. Zatim samo usputno spominje velikog naučitelja, tj. ističe kao uzor čistoću anđeoskog života svetoga Tome Akvinskoga čija je predavanja Augustin slušao (quem docentem audiverat) i za čiju je kanonizaciju dao svoj doprinos. ${ }^{14}$

Talijanski dominikanac Domenico Maria Marchese objavio je 1676. godine u Napulju Sagro Diario Domenicano, prikazujući u šest svezaka živote svetaca i blaženika Reda propovjednika za svaki dan u godini. U 4. svesku, na dan 3. kolovoza, u deset stupaca prikazuje Život blaženog Augustina, biskupa Lucere (Vita del Beato Agostino Vescovo di Lucera) te odmah navodi da su mu kao izvori poslužili Michele Piò (Plodio), Ivan Tomko Mrnavić, Sigismund Ferrarius i Časoslov blaženog Augustina koji se recitira u Luceri odredbom pape Ivana XXII. oko 1325. godine. Glede odnosa Augustina Kažotića i Tome Akvinskoga D. M. Marchese piše: »Stigavši u Pariz, imao je za učitelja veliko svjetlo Crkve, svetog Tomu Akvinskoga. « ${ }^{15}$

${ }^{12}$ Usp. Sigismundus Ferrarius, De rebus Vngarice Provincice, p. 116.

${ }^{13}$ Usp. ibid. Guillaume Cuypers spominje i kronologiju koju donosi Jean de Réchac u svom životopisu Augustina Kažotića na francuskom 1656. godine, u kojem navodi da je Kažotić 1259. ili 1260. išao u Pariz i tada slušao Tomina predavanja. No za te tvrdnje nema dokaza ni svjedoka. Stoga Cuypers radije slijedi Ferrariusovo tumačenje, usp. Acta sanctorum Augusti, t. I (Antverpiæ, 1733), p. 287.

${ }^{14}$ Usp. Ioannes Tomco, Vita Beati Augustini, u: Sigismundus Ferrarius, De rebus Vngaricae Provincice, Appendix, p. 36.

${ }^{15}$ Domenico Maria Marchese, Sagro Diario Domenicano, t. IV, p. 292ab: »Arriuato à Pariggi, hebbe per Maestro il gran lume della Chiesa S. Tomaso d'Aquino.« 
Godine 1747. pojavljuje se u Valenciji prijevod s talijanskoga na španjolski djela Sacro Diario Dominicano, nepoznatog autora, s kratkim prikazima života svetaca i blaženika Reda propovjednika za svaki dan u godini. I u tom se djelu također navodi da je Augustin Kažotić »sstudirao u Parizu u školi svetoga Tome Akvinskoga ${ }^{16}$

Poznati francuski dominikanac, biograf i povjesničar Antoine Touron (1686-1775) objavio je u Parizu u nekoliko svezaka Povijest glasovitih muževa reda svetoga Dominika (Histoire des hommes illustres de l'ordre de saint Dominique). U 2. svesku, objavljenom 1745, u devetoj knjizi, na trideset i pet stranica donosi opširan životopis »Svetog Augustina Kažotića, biskupa u Zagrebu u Slavoniji i potom u Luceri u Napuljskom kraljevstvu«. ${ }^{17}$ Pri pisanju životopisa Augustina Kažotića Touron se služi životopisom što ga je napisao Ivan Tomko Mrnavić, kojega povjesničari smatraju nepouzdanim i sklonim izmišljanjima. ${ }^{18}$ Antoine Touron poznaje da neki povjesničari tvrde da je Augustin Kažotić slušao predavanje Tome Akvinskoga. Stoga se distancira od takvih tvrdnji te piše:

»Nećemo reći, poput nekih povjesničara, da je Augustin Kažotić imao čast i pogodnost nastaviti svoj studij pod vodstvom svetoga Tome Akvinskoga. Naime, da se odbaci takvo mišljenje kao neodrživo, dostatno je znati da je sveti naučitelj preminuo u mjesecu ožujku 1274, tri ili četiri godine prije nego što je blaženi Augustin stupio u Red braće propovjednika, i dvanaest godina prije nego što će krenuti na put u Francusku. $\ll^{19}$

Antoine Touron odbacuje, dakle, mogućnost da je Augustin pohađao Tomina predavanja, ali na istom mjestu snažno ističe da je Augustin bio vjeran Tomin učenik i nasljedovatelj, tj. uvijek privržen Tominu nauku i nasljedovanju njegovih vrlina.

${ }^{16}$ Sacro Diario Dominicano, en el qual se contiene una breve insinuacion de las Vidas de los Santos, Beatos, y Venerables de la Orden de Predicadores para cada dia del Año, con alguna Reflexión, y Oracion, traducido de italiano en español, y añadido por Fr. Francisco Vidal (Valencia, 1747), pp. 354-355. (Agosto, Dia III. S. Agustin, Obispo de Lucera, Italiano), ovdje p. 355: »Estudiò en Parìs en la Escuela de Santo Thomàs de Aquino, adelantandose tanto en la virtud, y en las Ciencias, que despues de algunos años el Santo Benedicto XI. le nombrò Obispo Zagabriense.«»Studirao je u Parizu u školi svetog Tome Akvinskog, toliko napredujući u kreposti i znanosti, da ga je nakon nekoliko godina sveti Benedikt XI. imenovao biskupom zagrebačkim.«

${ }^{17}$ Antoine Touron, Histoire des hommes illustres de l'ordre de saint Dominique, sv. II, knj.

IX, pp. 1-35; hrv. prijevod u: Blaženi Augustin Kažotić 36/31 (2003), pp. 3-19.

${ }^{18}$ Tako Tamara Tvrtković tvrdi da je Ivan Tomko Mrnavić bio »zaluđen izmišljanjem«, usp. Ivan Tomko Mrnavić, Vita Petri Berislavi - Život Petra Berislavića, p. XX.

${ }^{19}$ Antoine Touron, Histoire des hommes illustres de l'ordre de saint Dominique, p. 4. 
U isto vrijeme dok Antoine Touron piše o Kažotiću na francuskom Baltazar Adam Krčelić (1715-1778) piše na hrvatskom kajkavskom jeziku svoj prvijenac, knjižicu Sivlenje Blasenoga Gazotti Augustina, zagrebechkoga biskupa, i tiska je u Zagrebu 1747. godine. Djelo je posvećeno tadašnjem zagrebačkom biskupu Juraju Branjugu. Krčelić piše da su dominikanci odlučili poslati Augustina Kažotića »vu Paris, Franczuszke zemlje naiglaszoviteju Skolu, da onde pod Tomassem od Aquine, Angelszkem Navuchitelom, velik i vu znanju i navukeh posztane. $\ll^{20}$ Krčelić se koristi raznim izvorima za pisanje svoga životopisa o Augustinu Kažotiću, posebice djelom Sigismunda Ferrariusa, Ivana Tomka Mrnavića i dr. Iako Ferrarius, na temelju jasnih povijesnih činjenica, ne prihvaća da je Augustin bio Tomin učenik u Parizu, Krčelić ne usvaja njegove razloge nego ostaje pri svome mišljenju da je Kažotić bio učenik Tome Akvinskoga u Parizu. Pri tome ostaje i kasnije, 1770, kad u svome djelu Povijest Stolne crkve zagrebačke piše: »Pišu da je bio učenik sv. Tome Akvinskog i zbog izuzetne naklonosti i jedinstvene vrline da je bio drag Anđeoskom naučitelju. (21 $^{21}$

Hrvatski hagiograf, pavlin Hilarion Gasparotti (1714-1762) objavio je 1760. u Beču na kajkavskome opsežno hagiografsko djelo Czvet szveteh, prikazujući živote svetaca kroz godinu. Na gotovo četrnaest stranica donosi Sitek Sz. Augustina Gazzoti biskupa zagrebechkoga. I on ističe da je Augustin poslan na studij u Pariz, na najpoznatije francusko sveučilište, da kod Tome Akvinskog, Anđeoskog naučitelja, napreduje u znanju i nauku.

"Za letom izvêrssenem, y trojvêrsztnem zavezom redovnichkem izpunyenem, na diku Reda: y Sz. Matere Czirkve haszen, Augustina vszeh osztaleh Redovnikov privolenyem va Pariz Franczuszke zemlye najglaszovitesse skole possalyu; da

${ }^{20}$ Usp. Baltazar Adam Krčelić, Sivlenje blasenoga Gazotti Augustina, zagrebechkoga biskupa, iz vnogeh szkup izebrano, i na peldu, i pobosnoszt. Vu Zagrebu, leta 1747. Po stampe Ivana Weitz, p. 5. Ibid., potvrđuje još jednom na p. 45. Transliterirani Krčelićev životopis Augustina Kažotića donosi Blaženi Augustin Kažotić 46/36 (2008), pp. 5-23; »<...> vu Paris, Francuske zemlje najglasoviteju Školu, da onde pod Tomašem od Aquine, Angelskem Navučitelom, velik i vu znanju i navukeh postane«, p. 8 i p. 15. Vidi također Stjepan Krivošić, »Krčelićevo 'Živlenje' zagrebačkoga biskupa Kažotića i njegovi izvori«, Forum 16/10-11 (1977), knj. 34, pp. 859-864, ovdje posebice p. 861; Alojz Jembrih, »Krčelićevo ‘Življenje blaženoga Auguština Kažotića (1747.)'«, Zaprešićki godišnjak 7 (1997), pp. 186-196.

${ }^{21}$ Baltazar Adam Krčelić, Povijest Stolne crkve zagrebačke, preveo Zlatko Šešelj (Zagreb: Institut za suvremenu povijest, 1994), p. 120; Historiarum cathedralis ecclesiae Zagrabiensis, p. I, t. I, cap. XIII, 21, pretisak (Zagreb, 1770; Zagreb: Institut za suvremenu povijest, 1994), p. 102: »S. Thomae Aquinatis scribitur fuisse Discipulus, \& Doctori Angelico ob excellens studium, singularesque Virtutes Charus.« 
onde pod Tomassom od Aquine Angelszkem navuchitelom dober vu znanyu, y navuku vuchini napredek. $\ll^{22}$

No i do polovice 20. stoljeća nailazimo, iako rjeđe, na tvrdnje da je Augustin Kažotić pohađao predavanja Tome Akvinskoga u Parizu. Spominjem ovdje samo još uglednog crkvenog povjesničara i liturgičara Dragutina Kniewalda (1889-1979) koji je proučavao zagrebačke liturgijske kodekse 30-40. godina 20. stoljeća i ulogu Augustina Kažotića na preuređenju liturgijskih knjiga u Zagrebu. Prikazujući red i čin mise po zagrebačkom obredu 13-14. stoljeća, uz rubriku konsekracije u zagrebačkim misalima, u svome djelu Liturgika iz 1937. profesor na Bogoslovnom fakultetu u Zagrebu piše: »Blaženi je Kažotić kao student u Parizu slušao sv. Tomu i vidio podizanje posvećenih prilika kruha, pa je kasnije, kao biskup zagrebački, u dotadašnji zagrebački obred, kome je on dao konačnu redakciju, unio i doktrinu svoga učitelja Tome Akvinca i praksu pariške crkve podizanja tijela Gospodnjeg. « $^{23}$ Slično piše i poznati hrvatski skotist Karlo Balić (1899-1977) proučavajući dominikanske kodekse u metropolitanskoj knjižnici u Zagrebu te tvrdi da su povezani s dominikanskim samostanom sv. Nikole u Zagrebu ili s »biskupom Kažotićem, koji je studirao u Parizu i, prema tradiciji hrvatskih dominikanaca, bio učenik sv. Tome Akvinskoga « ${ }^{24} \mathrm{U}$ toj tradiciji hrvatskih dominikanaca filozof Hijacint Bošković (1900-1947) ističe da je Augustin Kažotić »došao u Pariz baš u vrijeme kad je taj genij [Toma Akvinski] bio na usponu snage«, da je »vidio sve uspjehe svoga učitelja sv. Tome« te bio »očevidac svih onih trijumfalnih uspjeha koje je polučio njegov učitelj, Toma Akvinski«. ${ }^{25}$

\section{Augustin Kažotić i Toma u Parizu}

Godine 1259, na općoj skupštini Reda propovjednika u Valenciennesu, usvojen je studijski program (Ratio studiorum) koji je pripremalo petočlano povjerenstvo pariških profesora dominikanaca, tadašnja intelektualna elita Reda, među kojima su bili Albert Veliki i Toma Akvinski. Ističe se prioritet studija

${ }^{22}$ Hilarion Gasparotti, Czvét szvéteh, ali sivlenye, y chíni szvetczev, koteri vu nassem Horvatczkem, ilite Slovenszkem Országu..., vol. III (Beč, 1760), p. 338. Vidi također Franjo Galinec, »Dominikanac bl. Augustin Kažotić u svijetlu Gašparotijeve hagiografije 'Cvet sveteh' «, Kalendar Gospine krunice 4 (1937), pp. 24-32.

${ }^{23}$ Dragutin Kniewald, Liturgika (Zagreb: Tipografija, 1937), p. 349. Vidi također njegov rad: Obred i obredne knjige zagrebačke stolne crkve 1094. - 1788. (Zagreb: s. n., 1940), p. 19.

${ }^{24}$ Charles Balić, »Les anciens manuscrits de la Bibliothèque métropolitaine de Zagreb« (Bruges: Editions De tempel, 1948), p. 444.

${ }^{25}$ Usp. Hijacint Bošković, »Bl. Augustin Kažotić«, Duhovni život 6/5 (1934), p. 306. 
u odnosu na druge aktivnosti. Mlade studente, prikladne za studij, treba slati na generalna učilišta. U kući studija mladi trebaju dobiti temeljnu filozofsku izobrazbu. Odlučeno je također da se u provincijama pozorno bdije da nadarena braća budu poslana na studij na sveučilište u Parizu. O prisutnosti na Pariškom sveučilištu brinuo se vrhovni poglavar Reda (magister Ordinis). Potiče se mobilnost profesora koji se izmjenjuju u Parizu radi brzoga i kvalitetnoga formiranja što većega broja profesora kako bi u svakoj provinciji bilo dovoljno predavača.

U vrlo složenom i napetom doktrinarnom stanju na Pariškom sveučilištu vrhovni poglavar Reda propovjednika Ivan iz Verceila poslao je 1268. godine Tomu Akvinskog da ponovno, deset godina nakon njegova prvog pariškog profesorskog boravka (1256-1259), preuzme katedru iz teologije u Parizu. Nevjerojatno je što je sve Toma uspio ostvariti u tom razdoblju od 1268. do 1272. godine. Iz toga razdoblja potječe nekoliko od njegovih najpoznatijih djela, svetopisamskih komentara, raspravljenih pitanja (quaestiones disputatae) i većina (deset od dvanaest!) komentara na Aristotelova djela, što svjedoči o njegovu iznimno plodnom stvaralaštvu u Parizu. ${ }^{26}$

Nakon četiri godine predavanja u Parizu, a budući da je politika Reda favorizirala brzo izmjenjivanje profesora, Toma odlazi 1272. godine iz Pariza u Napulj. Provincijska skupština Rimske provincije, održana u Firenci u lipnju 1272 , povjerila mu je zadaću organiziranja novoga teološkog centra. Toma predaje kao profesor u Napulju do prosinca 1273. Početkom veljače 1274. Toma kreće na put prema Lyonu, gdje je papa Grgur X. sazvao koncil za 1. svibnja. Umro je u srijedu 7. ožujka 1274, u ranim jutarnjim satima, u opatiji Fossanova.

Prema općeprihvaćenoj kronologiji Augustin Kažotić dolazi u Pariz 1286. godine, dvanaest godina nakon Tomine smrti. Uočivši njegove intelektualne sposobnosti, redovnički poglavari poslali su Augustina na studij u Italiju, a zatim je pozvan na studij u Pariz. ${ }^{27}$ Toma Akvinski tada nije više predavao na Pariškom sveučilištu, nije bio više ni među živima. Ipak kod nekih autora čitamo kako je Kažotić slušao Tomina predavanja i bio vjeran učenik Anđeoskog naučitelja. Je li i na koji način Augustin Kažotić bio učenik sv. Tome?

Toma Akvinski je u više navrata po nekoliko godina boravio u Parizu. Najprije, u Parizu je pod vodstvom svog učitelja sv. Alberta Velikog studirao (1245-1248), a zatim u tri navrata po četiri godine i predavao. Prvi puta, nakon što je četiri godine (1248-1252) proveo kao student i asistent Alberta Velikog na tek osnovanom dominikanskom generalnom učilištu u Kölnu, Toma u Parizu

${ }^{26}$ Usp. Jean-Pierre Torrell, Initiation à saint Thomas d'Aquin. Sa personne et son oeuvre, (Fribourg - Paris: Universitaires de Fribourg, 2002), pp. 287-360.

${ }^{27}$ Usp. Michele Piò, Delle vite degli huomini illustri di S. Domenico, col. 241; izdanje iz 1620, col. 322-323; Jacques Quetif - Jacques Echart, Scriptores Ordinis Praedicatorum, t. I, p. 553. 
predaje od 1252. do 1256. kao sentencijski asistent (baccalaureus sententiarius), tumačeći četiri knjige Sentencija Petra Lombardijca. Iz toga razdoblja potječu tri njegova djela. U proljeće 1256. godine postaje redoviti profesor (magister actu regens) i u tom svojstvu predaje do 1259 , a piše i četiri djela. Toma ponovno kao profesor predaje u Parizu od 1268. do 1272. To je bilo, kako rekosmo, Tomino najplodnije spisateljsko razdoblje: desetak napisanih djela te deset od dvanaest komentara na Aristotelova djela.

Desetak godina provedenih na Pariškom sveučilištu te dvadeset $\mathrm{i}$ više napisanih djela za vrijeme svoga boravka u Parizu znak su da je Toma ostavio tragove snažne prisutnosti, koja se osjećala godinama i nakon njegove smrti. Štoviše, čim su saznali za Tominu smrt, rektor Pariškog sveučilišta i profesori fakulteta umijeća (artium) 2. svibnja 1274. pišu pismo na opću skupštinu dominikanskog reda koja se održavala u Lyonu, iskazujući svoju bol zbog smrti časnog naučitelja (doctorem venerabilem fratrem Thomam de Aquino). Uz najuzvišenije pohvale u spomen na slavnog naučitelja profesorski zbor u pismu podsjeća da su već pisali molbu na opću skupštinu u Firenci (1272) da se Toma vrati u Pariz, ali uzaludno. U znak dubokog poštovanja koje su mu iskazivali mole članove skupštine da im daju barem posmrtne ostatke onoga kojeg nisu mogli zadržati živog i ističu da bi bilo neprikladno položiti tako vrijedne relikvije drugdje osim u najslavnije sveučilište, na kojem je Toma crpio svoju znanost i koje je Toma proslavio. ${ }^{28}$ Pariški profesori također blagonaklono mole da im se

${ }^{28}$ Usp. Chartularium Universitatis Parisiensis, t. I, n. 447, p. 504: »Eum, quem a vestro collegio generali Capitulo vestro Florentie celebrato, licet requisissemus instanter, proh dolor, non potuimus obtinere tamen ad tanti clerici, tanti patris, tanti doctoris memoriam, non existentes ingrati, devotum habentes affectum, quem vivum non potuimus rehabere, ipsius jam defuncti a vobis ossa humiliter pro maximo munere postulamus, quoniam omnino est indecens et indignum, ut altera [natio] aut alius locus quam omnium studiorum nobilissima Parisiensis civitas, que ipsum prius educavit, nutrivit et fovit, et postmodum ab eodem nutrimenta et ineffabilia fomenta suscepit, ossa hec humata et sepulta habeat et detineat. Si enim merito ecclesia ossa et reliquias sanctorum honorat, nobis non sine causa videtur honestum et sanctum, tanti doctoris corpus in perpetuum honorem haberi, ut cujus famam apud nos scripta perpetuant, ejusdem perseverans memoria sepulture ipsorum in cordibus successorum nostrorum stabiliat sine fine.«»Njega, kojeg smo neprestano tražili od zbora vašega Generalnog kapitula slavljenog u Firenci, nažalost nismo mogli i zadržati, premda nismo nesvjesni uspomene na takvog svećenika, oca i naučitelja, ipak imamo pobožnu želju, da od vas ponizno zatražimo barem kosti njega preminuloga, jer ga nismo mogli imati dok je bio na životu. Jer bilo bi potpuno neprilično i nedostojno da drugi narod ili drugo mjesto, osim najslavnijeg sveučilišnog grada Pariza, koji ga je prvi obrazovao, hranio i za nj skrbio, a i kasnije je od njega primio hranu i neizrecivu blagodat, ima pokopane njegove kosti i da ih posjeduje. Naime, ako Crkva s razlogom časti kosti i relikvije svetaca, ne čini nam se bez razloga časnim i svetim da mi posjedujemo tijelo takvog naučitelja za trajno čašćenje i 
pošalju filozofski tekstovi koje su naručili od Tome dok je bio u Parizu; budući da su bili nedovršeni, nadaju se da ih je Toma dovršio nakon odlaska iz Pariza. ${ }^{29}$

U vrijeme kada Augustin dolazi na studij na Pariško sveučilište, iako je proteklo 14 godina otkako je na njemu predavao Toma Akvinski, njegov je nauk još uvijek bio živo prisutan u akademskim krugovima. Sačuvan je i popis Tominih djela položenih kod pariških knjižara oko 1275. godine, s devetnaest naslova, brojem sveščića i cijenom. ${ }^{30}$ Augustin Kažotić došao je u Pariz u vrijeme obilježeno velikim raspravama. U Parizu i u Oxfordu bio je znatno prisutan otpor protiv Tomine misli, o čemu svjedoče oštre i dugotrajne rasprave u kojima je oživjelo staro suparništvo između franjevačke i dominikanske škole. Pariški biskup Stjepan Tempier 7. ožujka 1277. osudio je 219 heterodoksnih teza. Augustin je, dakle, svjedok aktualnih teoloških i filozofskih previranja i rasprava toga vremena. Štoviše, vrijeme je to koje je obilježila vrlo prisutna tzv. literatura Correctoria. Naime, franjevački autori, posebice canterberijski nadbiskup Ivan Pecham i engleski franjevac Vilim de la Mare, profesor u Parizu i Oxfordu, donose brojne korekcije koje treba unijeti u Tomino djelo. Vilimov Correctorium, objavljen 1279, postaje službenim dokumentom na generalnom kapitulu franjevačkog reda Manje braće u Strasbourgu 1282. Tada je franjevački generalni ministar zabranio služiti se Tominom Sumom bez Vilimovih objašnjenja. ${ }^{31}$ Vilimov Correctorium dominikanci su prozvali Corruptorium i vrlo brzo napisali pet odgovora, braneći i promičući nauk Tome Akvinskoga. Tako se stvarala literatura Correctoria corruptorii. Dva su odgovora napisana u Parizu: Ivan Quidort (ili iz Pariza) oko 1282-1284 i Rambert dei Primadizzi (zvan također iz Bologne), koji se u to vrijeme nalazio u samostanu Sv. Jakova. Sva su djela napisali mladi dominikanci i nijedan od njih tada još nije bio redoviti profesor (magister regens), a pokazuju spekulativnu samosvijest

da kod nas djela nastave njegov dobar glas, a spomen na njegov ukop bit će trajno usađen u srca naših nasljednika.«

${ }^{29}$ Usp. ibid., pp. $504-505$.

${ }^{30}$ Usp. ibid., p. 646.

${ }^{31}$ Usp. »Definitiones Capituli generalis Argentinae celebrati anno 1282«, prir. Gerold Fussenegger, Archivum Franciscanum Historicum 26 (1933), pp. 127-140, usp. p. 139: »Generalis minister imponit ministris provincialibus quod non permittant multiplicari summam fratris Thome nisi apud lectores rationabiliter $<$ al. Notabiliter $>$ intelligentes, et hoc nisu cum declarationibus fratris Guillelmi de Mara, non in marginibus positis, sed in quaternis et huiusmodi declarationes non scribantur per aliquos seculares. «»Generalni ministar nalaže provincijalnim ministrima da ne dopuste umnažanje Sume brata Tome osim najsposobnijim lektorima, i to samo s tumačenjima brata Vilima de la Mare, ne na marginama nego u sveščićima, a takva tumačenja neka ne pišu svjetovnjaci.« Vidi također Frederick J. Roensch, Early Thomistic School (Dubuque: Priory Press, 1964), pp. 170-199. 
specifičnosti škole koja tek nastaje. ${ }^{32}$ Navodimo ovdje samo neke elemente po kojima se prepoznaje Tomino učenje krajem 13. stoljeća: ${ }^{33}$

- spoznaja univerzalnog i pojedinačnog (Toma je naučavao da je univerzalno vlastiti i izravni predmet našeg uma, dok um spoznaje pojedinačno samo neizravno i promišljanjem - per reflexionem);

- predmet proučavanja teologije i znanstvena značajka teologije;

- predmet metafizike, transcendentalne vlastitosti bića;

- stvarna razlika između biti i bitka u stvorenim bićima, što je Toma naučavao, izazvala je žestoke rasprave u posljednjoj četvrtini 13. stoljeća (gotovo svi prvi Tomini učenici podržavaju taj njegov nauk - protivnik npr. Henrik iz Genta u raspravi s Egidijem Rimskim 1286-1287);

- kristološke rasprave (jedinstvo bitka u Kristu; dvije naravi u Kristu tvore jednu osobu i jedan suppositum);

- rasprave iz trinitarne teologije: jedinstvo atributa u Bogu, različiti načini proizlaženja u Bogu, prvotnost osobnih vlastitosti, stvaralačko Trojstvo (Creatrix Trinitas) - stvaranje je zajedničko djelo svih triju osoba, status relacija u Bogu;

- jedinstvo supstancijalne forme - teza koja izaziva široke rasprave krajem 13. stoljeća;

- nematerijalnost anđela;

- vječnost svijeta;

- Bog ne prethodi svome učinku u pogledu trajanja;

- jedinstvo svijeta;

- slobodna volja - za Tomu čovjek je gospodar svojih čina.

Kažotićevi životopisci ističu da je došao u vrijeme kada se u Parizu održala opća skupština dominikanskog reda. A ta skupština iz 1286, slijedom odredbi prethodnih skupština održanih u Milanu (1278) i Parizu (1279), naređuje da se promiče nauk časnog učitelja brata Tome Akvinskoga:

»Strogo propisujemo i naređujemo da sva braća a i svaki pojedini nastoje uspješno, kako znaju i mogu, promovirati nauk časnog učitelja brata (venerabilis magistri fratris) Tome Akvinskoga, poštovane uspomene, barem kad je mišljenje moguće obraniti. Pokuša li netko formalno (assertive) činiti suprotno - bili oni profesori, bakalaureusi, lektori, priori ili druga braća, čak iako drukčije misle

${ }^{32}$ Usp. Mark D. Jordan, »The Controversy of the Correctoria and the Limits of Metaphysics«, Speculum 57 (1982), pp. 292-314.

${ }^{33} \mathrm{Za}$ širi tematski prikaz svake navede teze usp. Anto Gavrić, Une métaphysique à l'école de Thomas d'Aquin, pp. 99-139. 
- neka se ipso facto suspendiraju od vlastite službe i povlastica Reda, dok ih učitelj Reda ili Opća skupština ne vrati u prvotno stanje. $\ll^{34}$

\section{Toma - venerabilis doctor}

U svom traktatu De bonis et usu Christi et discipulorum seu apostolorum, $\mathrm{u}$ 3. pitanju o siromaštvu, »Je li siromaštvo samo po sebi savršenstvo ili sredstvo postizanja savršenstva? «, Augustin Kažotić Tomu Akvinskog naziva »časnim naučiteljem« (venerabilis doctor) koji je o tom pitanju opširno i razumno raspravljao te smatra da je to dostatno za istinit odgovor. ${ }^{35}$

Kažotić je svoju raspravu o siromaštvu napisao za vrijeme boravka u Avignonu (1321/1322), dok su se vodile burne rasprave o radikalnom poimanju siromaštva. Nazivajući Tomu Akvinskog »časnim naučiteljem« biskup Kažotić potvrđuje ne samo da on slijedi njegov nauk nego također koliko se doktrinarni autoritet Tome Akvinskog ustalio u dominikanskom redu i u crkvenom učiteljstvu.

Taj naslov, venerabilis doctor, najprije se spominje u već spomenutom pismu sućuti povodom Tomine smrti što su ga profesori fakulteta umijeća Pariškog sveučilišta 1274. uputili sudionicima opće skupštine dominikanskog reda u Lyonu. Zatim se u službenim zakonodavnim spisima dominikanskog reda uočava razvoj Tomina doktrinarnog autoriteta sve do uvođenja samoga naslova venerabilis doctor. Najprije se u zakonodavnim spisima općih skupština iz 1278, 1279. i 1286. nalaze nazivi koji ne govore o općem utjecaju nego izriču posebno poštovanje, od časnog oca, muža i učitelja: venerabilis patris fratris Thomae, venerabilis vir memoriae recolendae frater Thomas, venerabilis magistri fratris Thomae.

${ }^{34}$ Monumenta Ordinis Fratrum Praedicatorum Historica (MOPH), vol. I (Romae, 1898), p. 235: »Districtius iniungimus et mandamus. ut fratres omnes et singuli. prout sciunt et possunt. efficacem dent operam ad doctrinam venerabilis magistri fratris Thome de Aquino recolende memorie promovendam et saltem ut est opinio defendendam. et si qui contrarium facere. attemptaverint assertive; sive sint magistri sive bacallarii. lectores. priores et alii fratres eciam aliter sencientes; ipso facto. ab officiis propriis et graciis ordinis sint suspensi. donec per magistrum ordinis vel generale capitulum sint restituti. et nichilominus per prelatos suos seu visitatores iuxta culparum exigenciam; condignam reportent penam. « Taj tekst donosi i Chartularium Universitatis Parisiensis, t. II, n. 536, p. 6.

${ }^{35}$ Augustin Kažotić, »De bonis et usu Christi et discipulorum seu apostolorum«, u: Augustin Kažotić, Bogoslovni spisi-Scripta theologica, p. 92: »Quia per venerabilem doctorem tam copiose ac rationabiliter disputatum est, quod satis crederem ad quaestionis ueritatem sufficere.«»Jer, časni je naučitelj o tom opširno i razumno raspravljao, što držim dovoljnim za istinit odgovor.« 
Nakon opće skupštine u Parizu 1286. godine Tomino djelo i nauk postaje baština dominikanskog reda. Uz naredbu svim članovima reda da ga treba braniti od napada ističe se i obveza promicanja njegova učenja što će značiti da bi Tomina djela trebala postati osnovom ili čak priručnicima za poučavanje na dominikanskim učilištima. To se uočava kod Tominih učenika u Italiji koji kao glavni priručnik u svojim predavanjima koriste Sumu teologije pa provincijska skupština Rimske dominikanske provincije, održana u Perugi 1308, naređuje da u predavanjima slijede Sentencije. ${ }^{36}$ Opća skupština reda, održana u Saragossi 1309, naređuje svim lektorima i podlektorima da poučavaju »prema nauku i djelima časnog naučitelja brata Tome iz Akvina« (secundum doctrinam et opera venerabilis doctoris fratris Thomae de Aquino). Ista skupština dopušta dominikancima u inozemstvu da u slučaju nužde mogu prodati knjige osim Biblije i Tominih djela ${ }^{37}$ Sve do Tomina proglašenja svetim slično govori nekoliko općih skupština koje preporučuju proučavanje njegova naučavanja za koje se drži općenito kao sigurnije i više zajedničko (sanior et communior), tj. da ga većina profesora prihvaća kao najsigurnije, kao što ističe opća skupština u Metzu 1313. Ozbiljan trogodišnji studij Tomina nauka bio je nužan uvjet za slanje na studij u Pariz.

»Budući da se nauk časnog učitelja brata Tome Akvinskoga smatra zdravijim i univerzalnijim i da ga naš red treba posebno slijediti, strogo zabranjujemo da se nijedan brat, u predavanju, zaključnom mišljenju, odgovaranju usudi tvrditi suprotno onomu za što se općenito vjeruje da je mišljenje spomenutog učitelja, niti izreći ili potvrditi neko posebno mišljenje protiv zajedničkog mišljenja učitelja u onomu za što se zna da se odnosi na vjeru ili moral, osim pobijanjem i neposrednim odgovaranjem na prigovore $<$... $>$ Lektori također neka više nego obično tumače tekst Biblije, a u tumačenjima o Sentencijama neka obrade najmanje tri ili četiri članka iz nauka brata Tome, izbjegavajući preopširnost. Neka se nitko ne šalje na studij u Pariz, ako nije najmanje tri godine marljivo proučavao nauk brata Tome. « ${ }^{38}$

${ }^{36}$ Usp. Acta capitulorum provincialium Provinciae Romanae (1243-1344), prir. Thomas Käppeli - Antoine Dondaine, MOPH 20 (Romae: Institutum Historicum Fratrum Praedicatorum, 1941), p. 169: „Volumus et ordinamus firmiter observari quod lectores et baccellarii legant de Sentenciis et non de Summa Thomae. «»Hoćemo i naređujemo da se čvrsto obdržava da lektori i bakalaureusi predaju prema Sentencijama a ne prema Tominoj Sumi.«

${ }^{37}$ MOPH 4 (Romae, 1899), pp. 38 i 40.

${ }^{38}$ MOPH 4, pp. 64-65: »Cum doctrina venerabilis doctoris fratris Thomae de Aquino sanior et communior reputetur, et eam ordo noster specialiter prosequi teneatur, inhibemus districte, quod nullus frater legendo, determinando, respondendo audeat assertive tenere contrarium eius, quod communiter creditur de opinione doctoris praedicti, nec recitare aut confirmare aliquam singularem opinionem contra communem doctorum sentenciam in hiis, que ad fidem vel mores pertinere noscuntur, nisi reprobando et statim obiectionibus respondendo $<\ldots>$ Lectores quoque 
Sasvim je normalno da u Redu propovjednika svi budu vjerni Tominu učenju. Naredbe općih skupština strogo su se provodile. Tako skupština Rimske dominikanske provincije, održana 1315. u Arezzu, donosi sankcije protiv jednoga bakalaureusa iz Firence koji se udaljio od zajedničkog nauka, i »puno govorio protiv zdrave i svete nauke časnog naučitelja brata Tome Akvinskog «. ${ }^{39}$

Osim u službenim, zakonodavnim spisima dominikanskog reda taj se naslov spominje i u drugim izvorima. U literaturi replika Tominih učenika na Correctorium franjevca Vilima de la Mare, koja je vrlo svježa u vrijeme kad Kažotić dolazi u Pariz, više puta se ističe naziv venerabilis doctor kao i brojni drugi nazivi. A navode ga i drugi dominikanski autori, primjerice Bartolomej iz Lucce (1236-1327), koji je dovršio Tomino djelo O kraljevstvu (De regno), u svome djelu Povijest Crkve (Historia ecclesiastica), zatim u svojim djelima Meister Eckhart, Arman de Belvézer, Thomas Sutton te Vilim de Tocco u svom životopisu Tome Akvinskog prije same njegove kanonizacije (Hystoria Thomae de Aquino). ${ }^{40}$

Naslov venerabilis doctor u početku je bio samo izraz poštovanja u spomen na Tomu Akvinskog. No može se dokumentirano pratiti kako se taj naslov, usporedno s pojavom i razvojem štovanja prema Tomi, postupno pojavljuje, širi te s kanonizacijom 1323. konačno uspostavlja kao znak Akvinčeva doktrinarnog autoriteta. Po sebi je jasno da je dominikanski red imao važnu ulogu u porastu doktrinarnog utjecaja Tome Akvinskog. A u tome je svoj doprinos dao i Augustin Kažotić.

\section{Uškoli Tome Akvinskog}

Mnogi autori ističu da je Augustin Kažotić studirao u Parizu u školi svetoga Tome Akvinskoga, ne u smislu da je izravno slušao Akvinčeva predavanja nego da se intelektualno formirao u školi koja nastaje na temelju Tomina nauka i biva prepoznatljiva po svojim specifičnostima još prije njegove kanonizacije. Formiran u toj školi, Kažotić je i sam nastojao širiti nauk svog učitelja. Alfred Ciampi zaključuje: »Mišljenje da je naš blaženik bio učenikom sv. Tome, možda

de textu Bibliae plus solito legant et in lectura de Sententiis ad minus tres vel quatuor articulos de doctrina fratris Thomae pertractent, prolixitate onerosa vitata. Nullus etiam ad studium Parisiense mittatur, nisi in doctrina fratris Thomae saltem tribus annis studuerit diligenter."

${ }^{39}$ Usp. Acta capitulorum provincialium Provinciae Romanae (1243-1344), MOPH 20, p. 197: $»<\ldots>$ multa assertive dixit contra sanam et sacram doctrinam venerabilis doctoris fratris Thomae de Aquino.«

${ }^{40} \mathrm{O}$ razvoju i značenju toga naslova vidi više Antoine Dondaine, »Venerabilis doctor«, u: Mélanges offerts à Etienne Gilson (Toronto - Paris: Librarie philosophique J. Vrin, 1959), pp. 211-225. 
je nastalo ili se stalno utvrdilo stoga što je on duboko cijenio i privržen bio nauci Anđeoskog naučitelja, koja sja u njegovim djelima. «11 Kažotićeva privrženost nauku Tome Akvinskog vidljiva je na nekoliko područja.

Osobna knjižnica Augustina Kažotića, kao ni knjižnica dominikanskog samostana sv. Nikole u Zagrebu nije u potpunosti sačuvana. Istraživanja pokazuju da se ipak desetak dominikanskih kodeksa čuva danas u Metropolitanskoj knjižnici u Zagrebu, a povezani su sa samostanom sv. Nikole ili s biskupom Kažotićem. To su kodeksi označeni signaturama MR 14, MR 41, MR 56, MR 78, MR 79, MR 114, MR 140, MR 146, MR 150 i MR 162, a sadrže djela Aristotela, Tome Akvinskog, Alberta Velikog, Ivana iz Freiburga ( $† 1314)$, Nikole iz Gorana (1278), Rajnera Sacconija, Jakova iz Varazzea (de Voragine), Rajmunda Penjafortskog i dr. ${ }^{42}$ MR 146 objedinjuje više spisa koji se odnose na dominikansku povijest te pogotovo na djela i nauk Tome Akvinskog. Poznati hrvatski medievalist Karlo Balić, opisujući sadržajno taj kodeks, tvrdi da je sigurno bio kod Augustina Kažotića ${ }^{43}$ Drugi autori pripisuju svih deset sačuvanih kodeksa ostavštini biskupa Kažotića ${ }^{44}$ ističući kako oni pokazuju područja zanimanja svestrano obrazovanog biskupa i usmjerenost njegova pastoralnog djelovanja: filozofija, teologija, medicina, pravo, borba protiv krivovjerja, propovjedništvo, ispovijedanje i liturgija.

Dragutin Kniewald i Karlo Balić, u prvoj polovici 20. stoljeća, te u novije vrijeme Ivan Šaško, proučavali su zagrebačke liturgijske kodekse i osvjetljavali Kažotićev doprinos s obzirom na »zagrebački obred« i liturgijske promjene. Ovdje se zaustavljamo samo na jednoj specifičnosti zagrebačkog liturgijskog obreda u rubrici prije riječi posvete u misalu sa signaturom MR 133. U toj se rubrici u naznaci za posvetu kruha i vina donosi pojam transupstancijacije (transsubstantiatio), što potvrđuje privrženost biskupa Kažotića nauku Tome Akvinskoga, te se propisuje podizanje hostije i kaleža nakon posvete. Time je Kažotić u zagrebački liturgijski obred unio novu sasvim specifičnu rubriku. ${ }^{45}$

${ }^{41}$ Alfred Ciampi, Blaženi Augustin Kažotić, dominikanac - zagrebački zatim lučerski biskup (oko 1260.-1323.), preveo s talijanskoga Frano Kovačević OP, ciklostilom (Split - Trogir: Dijecezanski promicateljni odbor za kanonizaciju bl. Augustina Kažotića, 1959), p. 22.

${ }^{42}$ Usp. Charles Balić, »Les anciens manuscrits de la Bibliothèque métropolitaine de Zagreb«, pp. 444-460; Ivan Šaško, »Biskup Kažotić promicatelj knjige u Hrvata s posebnim naznakama iz povijesti liturgije«, Croatica Christiana Periodica 26/49 (2002), pp. 59-68.

${ }^{43}$ Usp. Charles Balić, »Les anciens manuscrits de la Bibliothèque métropolitaine de Zagreb«, p. 456.

${ }^{44}$ Usp. Ivan Šaško, »Biskup Kažotić promicatelj knjige u Hrvata s posebnim naznakama iz povijesti liturgije«, pp. 59-61.

${ }^{45}$ Usp. Charles Balić, »Une preuve du culte eucharistique en Croatie au XIV $\mathrm{s}$. Les rubriques de la consécration dans les anciens manuscrits liturgiques de la Bibliothèque métropolitaine de 
Verbis sequentibus panis transubstantiatur in corpus Christi verum:

(Sljedećim riječima kruh se pretvara u pravo tijelo Kristovo.)

Hic elevat supra corpus Domini $<\ldots>$

$<\ldots>$

Verbis sequentibus vinum transubstantiatur in sanguinem Christi verum: Hic est enim calix sanguinis mei $<\ldots>$

(Sljedećim riječima vino se pretvara u pravu krv Kristovu $<\ldots>$ )

Hic elevet calicem cum sanguine Christi <...>

Počevši od komentara na IV. knjigu Sentencija, preko IV. knjige Sume protiv pogana do Trećeg dijela Sume teologije nezaobilazna su pitanja o euharistiji, u kojima Toma Akvinski uvijek nastoji produbiti svoj pristup Sv. pismu, doći do što više patrističkih i koncilskih podataka i dokumenata, a ne zaobilazi ni obrede svoga vremena. Njegov traktat o euharistiji u Sumi teologije je prekrasan primjer srednjovjekovne sistematske teologije koji je kasnije itekako utjecao na jasno izricanje i definiranje katoličke nauke o euharistiji. ${ }^{46}$

Kod Tome je, kao i u teološkim traktatima drugih autora, uočljiva svjesna kritika senzualističke koncepcije, koja se pojavljuje u raspravama iz 11. stoljeća, posebice kad je riječ o stvarnoj nazočnosti. U svojoj kritici Toma se ne vraća na simboličku dimenziju nego ide prema metafizičkom promišljanju. U to vrijeme supstancija (substantia) postaje tehnički pojam koji se tumači uz pomoć aristotelizma. Metafizičko promišljanje je vidljivo u Akvinčevu izlaganju: »Nazočnost tijela Kristova u sakramentu nije ni na koji način ograničena prostorom. « ${ }^{47} \mathrm{Tu}$ nazočnost treba shvatiti analogno na način na koji je Bog nazočan u stvorenju: »Kad kažemo da je Krist u ovom sakramentu označavamo odnos Krista prema sakramentu. «48 Stoga kad nestanu euharistijske prilike $»<\ldots>$ tijelo Kristovo prestaje biti u njima, ne stoga što bi o njima ovisilo, nego zato što više nema odnosa tijela Kristova prema tim prilikama. $\mathrm{Na}$ isti način Bog prestaje biti Gospodarom stvorenja koje nestane. $\ll^{49}$

Za razumijevanje nauka o euharistiji svakako treba imati na umu koje mjesto zauzima transupstancijacija. Rasprava o transupstancijaciji nalazi se $\mathrm{u}$ kontekstu analize o »materiji« euharistije.

Zagreb«, Osoba i duh IV/3 (1952), p. 47 (239); Dragutin Kniewald, Liturgika, p. 349; Dragutin Kniewald, Obred i obredne knjige zagrebačke stolne crkve 1094-1788, p. 19; Ivan Šaško, »Biskup Kažotić promicatelj knjige u Hrvata s posebnim naznakama iz povijesti liturgije«, pp. 62-63.

${ }^{46}$ Opširnije vidi: Anto Gavrić, »Stvarna Kristova nazočnost u Euharistiji i pitanje transsupstancijacije prema sv. Tomi Akvinskom«, Izazov Istine 12/2(23) (2000), pp. 21-27. Ovdje preuzimam nekoliko ulomaka.

${ }^{47}$ Toma Akvinski, Summa theologiae III, q. 76, a. 5.

${ }^{48}$ Toma Akvinski, Summa theologiae III, q. 76, a. 6.

${ }^{49}$ Toma Akvinski, Summa theologiae III, q. 76, a. 6, ad 3. 
Srednjovjekovni teolozi svoje teološko promišljanje o euharistiji usredotočuju na Kristove riječi: »Ovo je tijelo moje, ovo je kalež krvi moje. «Toma piše da verba Christi, po kojima se događa posveta, djeluju sakramentalno. »Moć pretvorbe koja je u formama ovih sakramenata, slijedi njihovo značenje koje se završava izgovaranjem posljednje riječi.« To znači da cjelokupni izvanjski sakramentalni obred, djela i riječi, označava samo jednu jedinu stvarnost, tijelo i krv Kristovu. Supstancija kruha pretvara se u Kristovo tijelo, a supstancija vina u krv Kristovu. Transupstancijacija nije isto što i sakrament tijela i krvi Kristove. Tijelo koje Krist sada posjeduje u esse naturale transupstancijacijom, na otajstven način koji tomistička teologija izriče pojmom per modum substantiae, postaje nazočno tamo gdje je bio kruh. Sva se promjena događa u kruhu. A pretvorba supstancije kruha i tijela Kristova je sasvim nadnaravna. Transupstancijacija je skriveni Božji čin, skrivena moć koja od žrtve čini stvarnu žrtvu a ne samo simbol. Ona je u temelju sakramenta, duboko skrivena u ponoru samoga bitka gdje je Božja svemoć apsolutna.

Sv. Toma to prekrasno izriče u članku u kojem se pita preostaju li supstancije kruna i vina u ovom sakramentu i nakon posvećenja: »Bog je sjedinio 'svoje božanstvo', to jest božansku moć, s kruhom i vinom, ne da kruh i vino ostanu u tom sakramentu, nego da od kruha i vina učini tijelo i krv svoju.« Moć koju nazivamo transupstancijacijom ne ostaje u sakramentu, a ostaju tijelo i krv Kristova.

Kažotićeva privrženost Tomi vidljiva je i u njegovim spisima u kojima slijedi Akvinčev nauk, uključujući se u aktualne rasprave svoga vremena. Raspravu o siromaštvu Krista i njegovih učenika (apostola) napisao je, kako je bilo rečeno, za vrijeme boravka na papinskom dvoru u Avignonu (1321-1322), u ozračju žestokih rasprava o nasljedovanju Isusa Krista u radikalnom siromaštvu. U svojoj raspravi Kažotić se poziva na »časnog naučitelja« (doctor venerabilis), tj. na Tomu Akvinskog, ističući da je on o tome opširno i razumno raspravljao, što drži dovoljnim za istinit odgovor na to pitanje. ${ }^{50}$

A riječ je o trećem pitanju koje se odnosi na siromaštvo: »Je li ono (siromaštvo) po sebi savršenstvo ili sredstvo za postizanje savršenstva? ${ }^{51}$ Kažotić

${ }^{50}$ Usp. Augustin Kažotić, »O imetku Kristovu i učenika ili apostola i o njegovoj uporabi - De bonis et usu Christi et discipulorum seu apostolorum«, u: Augustin Kažotić, Bogoslovni spisi Scripta theologica, pp. 92-93: "Quia per venerabilem doctorem tam copiose quam rationabiliter disputatum est, quod satis crederem ad quaestionis veritatem sufficere. «»Jer, časni je naučitelj o tom opširno i razumno raspravljao, što držim dovoljnim za istinit odgovor.«

${ }^{51}$ Ibid.: »De tertio, scilicet de paupertate. Vtrum ipsa (paupertas) per se sit perfectio, uel perfectionis instrumentum? « $\mathrm{O}$ trećem pitanju, tj. o siromaštvu. Je li ono (siromaštvo) po sebi savršenstvo ili sredstvo postizanja savršenstva?« 
najprije potvrđuje da je Toma o tomu opširno (copiose) raspravljao, tj. da poznaje kako je Toma o tom pitanju raspravljao na više mjesta u svojim djelima. I doista, Akvinac je napisao nekoliko širih rasprava i više kraćih bilješki o siromaštvu, poglavito u pogledu biti redovničkog života. Pored dvaju kraćih djela u obranu prosjačkoga redovničkog života Contra impugnantes Dei cultum et religionem, napisanog u Parizu 1256, i De perfectione spiritualis vitae (1269-1270), opširne rasprave o siromaštvu sadrže djela Contra doctrinam retrahentium a religione (1271, poglavlja 14-16), Suma protiv pogana (Summa contra gentiles III, poglavlja 131-135) i Suma teologije (II-II, q. 184, a. 3 et 7; q. 186, a. 3 et 6; q. 188 , a. 7 , etc.). Toma obrađuje kraće i sažetije pojam siromaštva i siromašnog na mnogim drugim mjestima u svojim djelima i komentarima. Kažotić drži da je Tomino učenje o siromaštvu razumno i sasvim dovoljno za istinit odgovor na postavljeno pitanje, tj. da siromaštvo samo po sebi nije savršenstvo.

Tomin Quodlibet I, napisan oko 1269, potvrđuje da posvećivanje studiju i poučavanju za redovnike ne samo da nije grijeh nego je doista djelo savršenstva. A u odgovoru na drugi prigovor najavljuje dvije niti vodilje svojega stajališta o siromaštvu kao instrumentum perfectionis te razliku između savršenstva i staleža savršenstva. ${ }^{52}$ Toma se vraća na te dvije točke u svom djelu De perfectione spiritualis vitae. Za Tomu savršenstvo se ne nalazi u siromaštvu nego vrlo jasno ističe:

»Ako se pozorno razmotre Gospodinove riječi, nije savršenstvo stavio u samo odricanje od bogatstva, nego pokazuje samo kao put prema savršenstvu, kao što to pokazuje sam način govora kad kaže: 'Hoćeš li biti savršen, idi, prodaj sve što imaš, podaj siromasima i slijedi me' (Mt 19,21). To jest, savršenstvo se sastoji u nasljedovanju Krista, a odricanje pak od bogatstva je put prema savršenstvu. $\ll^{53}$

Vrlo blizak tome djelcu o savršenstvu duhovnog života jest i Tomin komentar na Matejevo evanđelje - Lectura super Matthaeum - koje jasno pretpostavlja raspravu iz 1270. godine o staležu savršenstva (status perfectionis). Zahtjev »biti savršen« $\mathrm{i} »$ sve dati siromasima« Toma tumači kao principium ili sredstvo koje doista omogućuje savršenstvo, ali to nije savršenstvo. Ono je više, kako pojašnjava primjer iz Evanđelja, u onom što slijedi »idi za mnom«, iz čega

${ }^{52}$ Usp. Toma Akvinski, Quodlibet I, q. 7, a. 2, ad 2, u: Quaestiones quodlibetales, izd. Raymund Spiazzi (Torino: Marietti, 1956), p. 14.

${ }^{53}$ Toma Akvinski, De perfectione spiritualis vitae, cap. 7: „Sed si verba domini diligenter considerentur, non in ipsa divitiarum dimissione perfectionem posuit; sed hoc ostendit esse quasi quandam perfectionis viam, ut ipse modus loquendi ostendit, cum dicitur: si vis perfectus esse, vade, et vende omnia quae habes, et da pauperibus, et sequere me: quasi in sequela Christi consistat perfectio, dimissio vero divitiarum sit perfectionis via." 
proizlazi da je odricanje od bogatstva samo put a ne već i cilj. Savršenstvo je ljubav prema Bogu, a odricanje od stvari je put koji vodi prema savršenstvu. ${ }^{54}$

Razlikovanje koje je Toma unio u Quodlibet I između cilja i sredstva vidljivo je u cijelom njegovu djelu. Teza da je siromaštvo instrumentum perfectionis nalazi svoj definitivni izričaj u Sumi teologije: »Savršenstvo se ne sastoji bitno u siromaštvu, nego u nasljedovanju Krista $<\ldots$.. $>$ Siromaštvo je naime kao sredstvo ili vježba koja pomaže da se dođe do savršenstva. « ${ }^{55}$ Siromaštvo u sebi nije ideal. Dragovoljno življenje siromaštva može biti znak duboke poniznosti. Bitna je ljubav prema Kristu koja nadahnjuje taj postupak. ${ }^{56}$

U Sumi protiv pogana Toma potvrđuje da siromaštvo samo po sebi nije dobro nego samo ukoliko oslobađa za duhovna dobra. ${ }^{57}$ Slijedom toga Toma promatra siromaštvo s obzirom na to koliko pomaže u postizanju svrhe i poslanja redovničke zajednice. Redovnička zajednica bit će savršenija u pogledu siromaštva ukoliko je siromaštvo prilagođenije i proporcionalnije njezinoj svrsi. ${ }^{58}$ Tim svojim stajalištem Toma kritizira franjevačko poimanje radikalnog siromaštva. Franjevački će autori žestoko napadati tomističku tezu o siromaštvu kao instrumentum perfectionis. To će činiti još više nakon Tomine kanonizacije jer će franjevci spiritualci kanonizaciju smatrati pravom provokacijom.

${ }^{54}$ Usp. Toma Akvinski, Super evangelium S. Matthaei lectura, cap. 19, ed. Raffaele Cai, p. 244: »Si vis perfectus esse, non quod statim sis perfectus, sed quoddam principium habebis perfectionis $\langle\ldots>$ sed in hoc quod sequitur est perfectio Et sequere me $<\ldots>$ Unde dilectio Dei est perfectio, sed demissio rerum est via ad pefectionem.«»Hoćeš li biti savršen, ne da bi odmah bio savršen, nego ćeš imati neki početak savršenstva $<\ldots>$ nego savršenstvo je u ovom što slijedi I idi za mnom $<\ldots>$ Stoga je ljubav prema Bogu savršenstvo, a odricanje od stvari je put prema savršenstvu.«

${ }^{55}$ Suma teologije II-II, q. 188, a. 7: »Perfectio non consistit essentialiter in paupertate, sed in Christi sequela, $<\ldots>$ paupertas autem est sicut instrumentum vel exercitium perveniendi ad perfectionem. « »Savršenstvo se ne sastoji bitno u siromaštvu, nego u nasljedovanju Krista $<\ldots>$ Siromaštvo je naime kao sredstvo ili vježba da se dođe do savršenstva.«

${ }^{56}$ Usp. Jean-Pierre Torrell, Initiation à saint Thomas d'Aquin. Sa personne et son oeuvre, pp. 122-139; John D. Jones, »Poverty and Subsistence: St. Thomas and the Definition of Poverty«, Gregorianum 75/1 (1994), pp. 135-149; John D. Jones, »The Concept of Poverty in St. Thomas Aquinas's Contra Impugnantes Dei Cultum et Religionem «, The Thomist 59/3 (1995), pp. 409-439; Ulrich Horst, Wege in die Nachfolge Christi. Die Theologie des Ordensstandes nach Thomas von Aquin (Berlin: Akademie Verlag, 2006).

${ }^{57}$ Usp. Suma protiv pogana III, pogl. 133.

${ }^{58}$ Usp. Suma teologije I-II, q. 108, a. 2, ad 3. 


\section{Augustin Kažotić i Tomina kanonizacija}

Više, naime, autora ističe ne samo da je Augustin Kažotić bio učenik Tome Akvinskoga nego ga povezuju i s Tominom kanonizacijom. Ivan Tomko Mrnavić u svome životopisu iz 17. stoljeća ističe da je Kažotić slušao Tomina predavanja i da je za njegovu »kanonizaciju dao svoj doprinos «. ${ }^{59}$ Opisujući posljednje trenutke života bl. Augustina Kažotića talijanski dominikanac Domenico Maria Marchese Sagro Diario Domenicano (1676) piše da je biskup Kažotić umro u 70. godini života, primivši utjehu što je »prije svoje smrti mogao vidjeti kanonizaciju svoga dragog učitelja Tome Akvinskoga, koju je silno želio«. ${ }^{60}$ I Antoine Touron piše da je tijekom 1322. godine »blaženi Augustin primio novi razlog radosti ugodnom viješću o kanonizaciji svetog Tome Akvinskog, koju je žarko želio i za koju se gorljivo zauzimao. ${ }^{61}$ Kažotić je bio privržen Akvinčevu učenju što se može vidjeti na nekoliko područja, zbog čega se dugo držalo da je bio izravnim učenikom Anđeoskog naučitelja. Tako prigodom 600 . obljetnice Kažotićeve smrti Ivan Vuletin 1923. piše:

»Umro je kao pravednik i u glasu velike svetosti, a najviše radostan da mu se je ispunila želja, što je dočekao, da je Toma Akvinski, njegov bivši učitelj u Parizu, bio proglašen svecem. On je svoju želju još za života bio izrazio papi i živo o tome nastojao. Šest dana prije smrti donijeli su mu veselu vijest, da je papa Ivan XXII. na 18. srpnja proglasio svecem Tomu Akvinskoga. «62

A Alfred Ciampi u svom dokumentiranom životopisu glede ubrajanja Kažotića u izravne Tomine učenike zaključuje: »Možda je izvorom toga mišljenja i veliko zanimanje što ga je Augustin razvio na dvoru Anžuvinaca i kod Svete Stolice u Avignonu, sa svrhom da se pospješi Tomina kanonizacija. $\ll^{63}$

Nakon dvogodišnje sedisvakancije za papu je 7. kolovoza 1316. izabran francuski kardinal Jacques Duèse koji je imao sedamdeset dvije godine, a uzeo je ime Ivan XII. Papa, vrlo naklonjen Anžuvincima, od samog početka se zanimao za kanonizaciju Tome Akvinskoga, čija je djela veoma cijenio, te je podupro

\footnotetext{
${ }^{59}$ Usp. Ioannes Tomco, »Vita Beati Augustini«, u: Ferrarius, De rebus Vngarica Provincice, Appendix, p. 36.

${ }^{60}$ Domenico Maria Marchese, Sagro Diario Domenicano (Napoli: Nella stamperia di Giacinto Passaro, 1676), t. IV, p. 295a.

${ }^{61}$ Usp. Antoine Touron, Histoire des hommes illustres de l'ordre de saint Dominique, t. II (Paris: Babuty, 1745), knj. IX, p. 30.

${ }^{62}$ Ivan Vuletin, Život bl. Augustina Kažotića, biskupa Zagrebačkoga i Lucerinskoga, rodom Trogiranina, Reda sv. Dominika (Šibenik: Hrvatska zadružna tiskara, 1923), p. 27.

${ }^{63}$ Alfred Ciampi, Blaženi Augustin Kažotić, dominikanac - zagrebački zatim lučerski biskup, p. 22. Ciampi u bilješci br. 11 navodi: Angiullo T. M. 1665 dela Biblioteca Comunale di Lucera, cap. 26. (Poglavlje 26. rukopisa br. 1665, koji se čuva u općinskoj knjižnici u Luceri).
} 
molbu što mu je uputila Dominikanska provincija Kraljevstva Sicilije koja je na kapitulu u rujnu 1317. imenovala Vilima de Tocco promotorom postupka za Tominu kanonizaciju a Roberta iz Beneventa njegovim sociusom. ${ }^{64}$

U srpnju ili kolovozu 1318. Vilim de Tocco pohodio je Avignon, zajedno sa svojim sociusom. U Avignonu se sastao s Bernardom Guiom, prokuratorom Reda propovjednika, koji je po službi bio posrednik između Reda i Svete Stolice. Susreo je također tada najvećeg crkvenog povjesničara Bartolomeja iz Lucce. Tocco je papi predao molbu za kanonizaciju, prvi popis čuda po Tominu zagovoru i prvu redakciju svoga djela Hystoria Thomae de Aquino. Papa Ivan XXII. službeno je otvorio postupak 13. rujna 1318. Krajem 1320. ili početkom 1321. Vilim de Tocco je sa svojim sociusom ponovno u Avignonu, s popisom čudesa koja su se dogodila u Fossanovi, gdje je Toma umro na putu za koncil u Lyonu, i konačnom verzijom teksta Hystoria. Papa i njegovi savjetnici držali su da ima još mnogo svjedoka koji nisu saslušani te zatražio da se istraživanje nastavi u Fossanovi i da se zabilježe sva čuda koja su se tamo dogodila.

Papa Ivan XXII. proglasio je Tomu Akvinskog svetim 18. srpnja 1323. bulom Redemptionem misit. Uoči kanonizacije papa je na svečanom konzistoriju kardinala i biskupa izrekao govor u kojem je isticao Tomino učenje o redovničkom siromaštvu. Na početku je izrekao pohvalu dominikanskom idealu siromaštva, prema kojemu braća ne posjeduju ništa vlastito i privatno, ali posjeduju nešto zajednički, poput apostola. I tada je papa dodao: »A držimo da je to apostolski život.« Ta se Papina teza odnosila na tadašnju teološku raspravu o franjevačkom siromaštvu. Papa je nastavio tvrdeći da je Toma, nakon apostola i prvih crkvenih naučitelja, kao nitko drugi obasjao svijet svjetlom istine. Uočljiva je doktrinarna perspektiva u riječima pape Ivana XXII. koji je snažno pohvalio Tomin nauk o redovničkom siromaštvu. Pristaše dragovoljnog siromaštva u krugovima zanesenjaka franjevaca spiritualaca smatrali su Tominu kanonizaciju, kako je već bilo spomenuto, pravom provokacijom. ${ }^{65}$

Kažotić je kao član povjerenstva od deset eksperata sudjelovao u Avignonu na konzistoriju 6. ožujka 1322. radi pripremanja redakcije bule pape Ivana XXII.

\footnotetext{
${ }^{64}$ Više o postupku Tomine kanonizacije vidi Jean-Pierre Torrell, Initiation à saint Thomas d'Aquin. Sa personne et son oeuvre, pp. 465-475; James A. Weisheipl, Frère Thomas d'Aquin. Sa vie, sa pensée, ses oeuvres (Paris: Cerf, 1993), pp. 377-383; Angelus Walz, »Historia canonizationis sancti Thomae de Aquino«, u: P. Sadoc Szabo (ur.), Xenia thomistica, sv. III (Rim: Typis Polyglottis Vaticanis, 1925), pp. 105-172; A. Walz, »Papst Johannes XXII. und Thomas von Aquin. Zur Geschichte der Heiligsprechung des Aquinaten«, u: Armand A. Maurer (ur.), St. Thomas Aquinas 1274-1974 Commemorative Studies, sv. 1 (Toronto: Pontifical Institute of Medieval Studies, 1974), pp. 29-47; Pierre Mandonnet, »La canonisation de saint Thomas d'Aquin, 1317-1323«, u: Mélanges thomistes I (Le Saulchoir, Kain: Revue des sciences philosophiques et théologiques, 1923), pp. 1-48.

${ }^{65}$ Usp. Torrell, Initiation à saint Thomas d'Aquin, p. 473.
} 
Cum inter nonnullos (12. studenog 1323), kojom je osudio nauk o radikalnom siromaštvu franjevaca spiritualaca. ${ }^{66}$ Augustin Kažotić u svojoj raspravi zastupa Tominu tezu o siromaštvu kao sredstvu za postizanje savršenstva (instrumentum perfectionis). U odgovoru na treće pitanje, pozivajući se na časnog naučitelja čiji nauk drži dovoljnim za istinit odgovor, Kažotić više puta ponavlja te na kraju potvrđuje da »siromaštvo po sebi nije savršenstvo«. ${ }^{67}$ Čini se da Kažotićevo isticanje dostatnosti $\mathrm{i}$ istinitosti Tomina nauka o poimanju siromaštva ima puno šire značenje i doprinos u kontekstu u kojem je napisana njegova rasprava, i značajan doprinos u postupku kanonizacije Tome Akvinskoga.

Je li se Vilim de Tocco susreo s Augustinom Kažotićem na papinskom dvoru u Avignonu? Nema za to povijesnih naznaka. No poznato je da je Kažotić stigao u Avignon u drugoj polovici te iste, 1318. godine. Vrlo vjerojatno su biskupu Kažotiću bili poznati napori da se ubrza postupak Tomine kanonizacije. Vjerojatno je Kažotić bio među onima koji su na dvoru Anžuvinaca razvili veliko zanimanje za Tominu kanonizaciju. Naime, dok je Vilim de Tocco, kao postulator kauze, prikupljao podatke o Tomi Akvinskom, primio je peticije za Tominu kanonizaciju od kraljice Marije Arpadović ( $†$ 25. 3. 1323), udovice kralja Karla II. Anžuvinca, i brojnih drugih napuljskih velikaša da ih preda papi ${ }^{68}$ Papa Ivan XXII. bio je naklonjeniji dvoru Anžuvinaca, koji su podupirali kanonizaciju Tome Akvinskog, negoli dvoru aragonskog kralja, koji je predlagao kanonizaciju Rajmunda Penjafortskog. ${ }^{69}$ Osim toga, sam je Karlo Anžuvinac, sin Roberta Anžuvinca, koji je bio vojvoda Kalabrije i potkralj Napulja, osobno poznavao biskupa Kažotića; nakon pohoda njegovu grobu u Luceri, 20. listopada 1325. uputio je molbu papi Ivanu XXII. da započne kanonski postupak za proglašenje svetim. ${ }^{70}$

U svojoj molbi, ističući svetost života biskupa Kažotića i čudesa koja se događaju po njegovu zagovoru, Karlo Anžuvinac piše:

»Kao što sam iz pouzdanih vrela saznao, nije Vašoj Blaženosti bilo nepoznato kakvu je iskrenost života pokazivao, kako je izvanredno bio jasan u znanostima

${ }^{66}$ Usp. Alain Boureau, Satan hérétique. Naissance de la démonologie dans l'Occident médiéval (1280-1330) (Paris: Odil Jacob, 2004), pp. 64 i 69.

${ }^{67}$ Augustin Kažotić, O imetku Kristovu i učenika ili apostola i o njegovoj uporabi, p. 93.

${ }^{68}$ Usp. Weisheipl, Frère Thomas d'Aquin, p. 378.

${ }^{69}$ Usp. Torrell, Initiation à saint Thomas d'Aquin, p. 465. Naime, papa Ivan XXII. htio je pokazati zahvalnost dominikanskom redu za održavanje konklava u Lyonu tijekom dvije godine kanonizirajući jednog od njegovih članova.

${ }^{70}$ Latinski tekst molbe donosi Alfred Ciampi, Blaženi Augustin Kažotić, dominikanac, pp. 185-187; hrvatski prijevod u: Marijan Biškup, Blaženi Augustin Kažotić (o. 1260. - 1323.): biskup, prosvjetitelj i zaštitnik siromaha (Zagreb: Glas Koncila - Dominikanska naklada Istina, 2002), pp. 131-133. 
i siromašnima dijelio izdašnu milostinju, dok je još bio živ među nama. I ja sam, Velečasni moj Gospodine, Bog mi je svjedok da govorim čiste savjesti, čim je on stigao u ove krajeve, više puta s njime razgovarajući shvatio i vidio u njegovim riječima, u licu, u gestama, kako je ljubazan bio njegov razgovor i da je sve što je u njemu bilo izvornog, i znanje i kreposti, bilo na spasenje duša. « ${ }^{71}$

\section{Zaključak}

Augustin Kažotić je kod svojih suvremenika bio prepoznat po učenosti, kreposnom životu i socijalnoj osjetljivosti. Dominikanac Bernard Gui o njemu piše da je bio »vir litteratus et bonus«, učen i dobar, tj. svet. Vilim Adam ističe Kažotićevu ljubav prema siromaštvu. Zagrebački misal (MR 133, 1. 159), napisan između 1323. i 1326, tj. odmah nakon Kažotićeve smrti, donosi obrazac za misu bl. Augustina: »Na blagdan blaženog Augustina, nekoć biskupa zagrebačke Crkve, priznavaoca, velikog propovjednika i učitelja kada bude proglašen svetim«. Misal ističe Kažotićeve odlike velikog propovjednika i učitelja (magni praedicatoris et doctoris). I u svim se tim dimenzijama uočava poveznica sa sv. Tomom. Promišljajući kvalitete propovjednika, Toma Akvinski ističe ove tri koje mu se čine bitnima: čvrstoća (stabilitas), da se ne bi udaljio od istine; jasnoća (claritas), da ne bude nejasan u naučavanju i korisnost (utilitas), da traži Božju a ne svoju slavu. ${ }^{72}$ Propovjednik je privržen molitvi i studiju kojima prodire u otajstvo kako bi ga prenio drugima.

Raspravljajući o hijerarhiji kreposti Toma Akvinski piše da je »između svih kreposti koje se odnose na bližnjega milosrđe najizvrsnija krepost«. Njezina je zadaća darivati drugima, i ono što je najvažnije, ublažavati oskudicu drugih. Bogu je najugodnija žrtva milosrđe kojim se ublažava bijeda i oskudica potrebitih, jer se činom milosrđa nadasve traži dobro bližnjega. ${ }^{73}$ Kontemplacija čini nesebičnim i osjetljivim za pravednost. Augustinovi suvremenici i životopisci ističu da ga je krasio nesebičan i milosrdan pogled prožet ljubavlju, koji je prepoznavao potrebe i nevolje povjerena mu stada u biskupijama u Zagrebu i Luceri, da je nastojao ublažiti nevolje, da se borio protiv svakog oblika nepravde, za obranu prava siromašnih i prezrenih, i zauzimao za dostojanstvo ljudske osobe. Može se s pravom isticati kao zaštitnik socijalne pravde.

${ }^{71}$ Preuzeto iz: Biškup, Blaženi Augustin Kažotić, p. 132.

72 Toma Akvinski, Super evangelium S. Matthaei lectura, cap. 5, ed. Raffaele Cai (Torino - Rim: Marietti, 1952), n. 456: »Primum est stabilitas, ut non deviet a veritate; secundum est claritas, ut non doceat cum obscuritate; tertium est utilitas, ut quaerat Dei laudem et non suam."

${ }^{73}$ Usp. Toma Akvinski, Suma teologije II-II, q. 30, a. 4, i ad 1. 
No još je i danas život Augustina Kažotića malo poznat. Formiran je u filozofiji i teologiji na prvim izvorima tomističke škole o čemu svjedoče njegova djela. Postavši biskupom u Zagrebu, obnovio je katedralnu školu, središte studija prema modelu studia prosjačkih redova, u kojima se školovao i u kojima je zasigurno i predavao. Obnova katedralne škole samo je jedan od plodova Kažotićeva boravka u Zagrebu (1303-1318). Poznati hrvatski filozof Hijacint Bošković, povezujući Kažotića s Akvincem i ističući Kažotićevo obrazovanje u tomističkom nauku, naslućuje da je to studijsko središte u Zagrebu bilo »prvo žarište tomizma u nas «. ${ }^{74}$

Život Augustina Kažotića, dominikanca, pariškog studenta, zagrebačkog biskupa, papinog savjetnika u Avignonu i naposljetku biskupa u Luceri, dobar je primjer uspjeha srednjovjekovnoga pariškog sveučilišta, ali i pokazatelj političko-vjerskih sukoba u vrijeme pojave nacija koji karakteriziraju kršćanstvo iz vremena avignonskog papinstva. On je ujedno i vrijedno svjedočanstvo za poznavanje prenošenja misli sv. Tome Akvinskoga, u razdoblju prije same njegove kanonizacije.

\section{Augustin Kažotić and Thomas Aquinas}

\section{Summary}

The study of the first generation of students of Thomas Aquinas has remained quite unexplored. Studies of Thomas's first students are particularly important for knowing how the thought of the Doctor communis was transmitted and in what areas. Therefore, this paper also enters this area of research. The article first shows how for centuries it has been pointed out in various sources that Augustin Kažotić was a direct student of Thomas Aquinas and that he attended his lectures while studying at the University of Paris. The author then doctrinally analyse the context of Augustin's stay in Paris to study, showing that Thomas's teaching was still vividly present in academic circles. The author further confirms that the Dominican Order played an important role in the growth of the doctrinal influence of Thomas Aquinas and shows that Augustin Kažotić also contributed to this. Therefore, the author analyzes Kažotić's connection with Thomas Aquinas in several doctrinal areas. Finally, he judges the contribution of Augustin Kažotić to the canonization of Thomas Aquinas. The article confirms that the life and work of Augustin Kažotić is a significant testimony to the knowledge of the transmission of the thoughts of St. Thomas Aquinas, especially in the period before his canonization.

Key words: Augustin Kažotić, Thomas Aquinas, transubstantiation, poverty, Thomism

\footnotetext{
${ }^{74}$ Usp. Hijacint Bošković, »B1. Augustin Kažotić«, p. 307.
} 


\section{-}

